\title{
CAMERA TRAPS TO STUDY THE FOREST ELEPHANT'S (LOXODONTA CYCLOTIS) RESPONSE TO CHILLI PEPPER REPELLENT DEVICES IN GAMBA, GABON
}

\author{
Steeve Ngama ${ }^{1,2}$, Lisa Korte ${ }^{3}$, Mireille Johnson ${ }^{3}$, Cédric Vermeulen', Jérôme Bindelle ${ }^{1}$ \\ ${ }^{1}$ Gembloux ABT, University of Liège, Belgium \\ e-mail:steeve.ngama@doct.uliege.be,cvermeulen@uliege.be,jerome.bindelle@uliege.be \\ ${ }^{2}$ Agronomic and Forestry Research Institute, National Center for Scientific and Technological Research, Gabon \\ e-mail: steeve_ngama@yahoo.fr \\ ${ }^{3}$ Smithsonian Conservation Biology Institute, Gabon Biodiversity Program, USA \\ e-mail:lisakorte@earthlink.net,JohnsonMI@si.edu
}

Received: 16.02.2018

\begin{abstract}
In Central Africa, Gabon is a forested country with a rich biodiversity where conflict between wild animals and humans is common and causes innumerable damage to crops. The worst crop raiders are elephants, which can destroy an entire crop in a single night. These raids threaten people's livelihoods as well as elephants because angry farmers often retaliate with killing campaigns against crop raiding elephants. To keep elephants out of farms the use of chilli pepper is recommended as a non-lethal method. But only a few studies have tested methods to use chilli pepper to deter elephants in Gabon. Results from this study give a starting point for understanding how forest elephants react to devices using chilli pepper as a deterrent based on sequential camera trap photos. A chilli pepper device that resulted in splashing concentrate on the elephant face proved to be the most effective at deterring elephants. Surprisingly, chilli pepper concentrate directly applied to mango fruits did not deter elephants from eating the fruits, although it probably caused some discomfort. To make effective deterrent devices with chilli pepper future works need to focus on exploring practices to reach the elephant face with the least, safe quantity of chilli pepper and which will have enough strong deterrent effect.
\end{abstract}

Key words: camera trap, Central Africa, chilli pepper, forest elephants, Gabon

\section{Introduction}

In Central Africa, the forested country of Gabon is inhabited by more than half of the remaining forest elephant (Loxodontata cyclotis Matschie, 1900) population (Blanc et al., 2007, 2013). Forest elephant numbers have declined dramatically in the last decade, with poaching being the primary threat to this species (Maisels et al., 2013; Poulsen et al., 2017). Crop raiding by elephants is an important secondary threat that often turns rural people against elephant conservation (Hoare, 2015; Mariki et al., 2015).

Elephant crop-raiding has negative consequences for both rural farmers and elephants. Elephants can threaten the livelihoods of rural farmers, slow economic development of local communities and cause human death and injury (Tchamba, 1995; Walker, 2012). In Northern Cameroon elephant damage to crops have been estimated between $\$ 40,000$ to $\$ 75,000$ per year in a country where the annual guaranteed minimum wage rate is $\$ 840$ (Tchamba, 1995). In the Democratic Republic of Congo, elephant damage to crops can decrease farmer annual revenues by 77\% (Inogwabini et al., 2013). In rural Gabon resentment against elephants is widespread because elephants can destroy an entire year's crop in a single intrusion (Fairet, 2012; Walker, 2012). Loss of lives, crops, money, effort, and time fuels resentment against elephants that often results to retaliatory killings and drives people to look for alternate/lethal deterrent methods against elephants (Tchamba, 1995; Hoare, 2015; Mariki et al., 2015).

Local people use a variety of methods to protect crops from elephants (Fairet, 2012; Walker, 2012). These methods range from erecting scarecrows in fields to building barriers and deterrents such as fires, clearing the perimeters of fields and setting up metal string fences with noisemakers (Lahm, 1993; Walker, 2010; Fairet, 2012). Communities also work collectively following group crop guarding in a single area that is easier to monitor and to protect with sophisticated methods such as electrified fences (Fairet, 2012; Walker, 2012; Hoare, 2015). Unfortunately, sophisticated methods are too expensive and elephants almost always find ways to overcome these measures, underscoring the urgent need to develop simple, effective and non-lethal methods such as the use of chilli pepper (Hoare, 2015; Chang'a et al., 2016). 
Chilli pepper is an elephant non-palatable crop known in East Africa as efficient in deterring the savanna elephant (Loxodonta africana africana (Blumenbach, 1797)) subspecies (Parker \& Osborn, 2006; Hedges \& Gunaryadi, 2010, Wiafe \& Sam, 2014, Le Bel et al., 2015; Chang'a et al., 2016). Although many chilli pepper species are present and cultivated, few studies have been tested on methods to use chilli pepper to deter elephants in Gabon. We set out to investigate how the forest elephant subspecies will react to chilli pepper devices, and used camera traps to record the elephant behaviour.

Scientists use cameras in animal biology allowing multiple research objectives to be addressed including ecology and behaviour (O'Connell et al., 2011; Trolliet et al., 2014; Howe et al., 2017). More recently, researchers increasingly use camera traps to study wildlife, including research on elephant behaviour (Ngama et al., 2016; Howe et al., 2017; Smit et al., 2017). The aim of this study was to use camera trap to better understand how elephants react to chilli pepper used as a repellent. We predicted that (1) elephants would avoid feeding on fruits in trees protected and equipped with chilli devices; and that (2) they would not eat mango fruits mixed with a chilli pepper concentrate.

\section{Material and Methods}

\section{Study site}

This study was conducted near the town of Gamba $\left(1^{\circ} 55^{\prime} \mathrm{S}, 9^{\circ} 50^{\prime} \mathrm{E}\right)$ in the Gamba Complex of Protected Areas in South-West Gabon in Novem- ber 2011. The Gamba Complex consists of two national parks (Loango, $1550 \mathrm{~km}^{2}$ and MoukalabaDoudou, $4500 \mathrm{~km}^{2}$ ) that are longitudinally divided by an industrial corridor for oil production and timber harvesting called the Rabi-Ndogo Protected Area $\left(3500 \mathrm{~km}^{2}\right)$ (Lee et al., 2006). The region experiences bimodal rainfall with a short dry season in January and a long dry season extending from June to August and rains during the rest of the year (Lee et al., 2006). The mean annual rainfall is 2093 $\mathrm{mm}$, relative humidity is around $85 \%$ and the average temperature ranges from $24^{\circ} \mathrm{C}$ to $28^{\circ} \mathrm{C}$ (Lee et al., 2006). As in many places in Gabon, the humanelephant conflict occurs in the Gamba Complex of Protected Areas (Lee et al., 2006; Walker, 2010).

Since the start of oil production in 1960, Gamba has grown from a small fishing village to a town of approximately 9,000 people letting more contacts between people and wildlife (Lee et al., 2006). The study was carried out at the Eastern part of the residential Yenzi Camp within Gamba (Fig. 1). This camp has approximately 140 homes and 500 residents covering about $0.4 \mathrm{~km}^{2}$ where more than 150 mango trees (Mangifera indica L.) have been planted among residences. From October to December, when mango trees are fruiting, elephants enter the camp to feed on ripe mangos. At least 30 elephants visit the camp, moving between mango trees. This creates a unique opportunity to observe wild forest elephants and test different methods such as using hot chilli peppers to deter elephants from feeding on mango fruits.

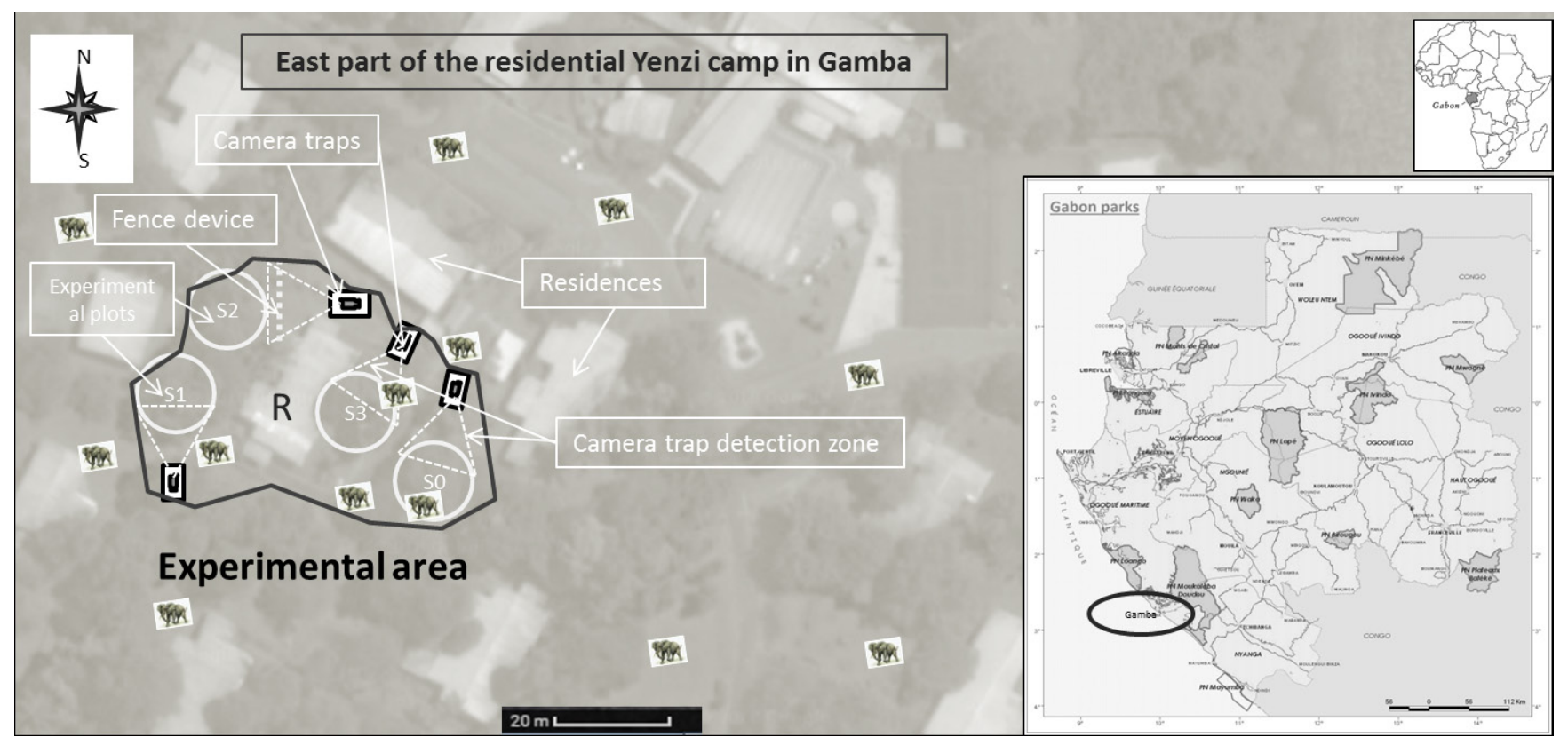

Fig. 1. Schematic view of the experimental site in the residential Yenzi Camp in Gamba. S0 = control site without chilli; S1 $=$ site with a fence of chilli pepper device; S2 = a site equipped with bottles releasing chilli pepper smell; S3 = a site where mango fruits were coated with the chilli pepper concentrate; $\mathrm{R}=$ residence of lead author during the study period. Adapted from Google Earth (2018) and Gabon Park map (2012). 
We prepared a concentrate of hot chilli pepper mixed with oil to test how wild forest elephants would react to chilli pepper as a deterrent. Two species of chilli peppers were used: Capsicum annuum L. and Capsicum pubescens Ruiz \& Pav. (Csilléry, 2006) locally known as yellow and red hot peppers. We followed recommendations provided by the Elephant Pepper Development Trust and methods from Hedges \& Gunaryadi (2010) to make chilli pepper grease. We replaced engine grease with edible commercial cooking palm oil to not poison elephants because we aimed to test elephant reactions when sensitive body parts such as eyes, trunk and mouth mucosae make contact with chilli pepper devices. To avoid a noxious overdose, we used a ratio of $1 / 2$ of fresh local red and yellow hot chilli peppers and cooking palm oil instead of the 1/1 recommended ratio. Chilli peppers were crushed using a manual grinder. As frying is better than boiling to maintain chilli pepper characteristics (Chuah et al., 2008; Ornelas-Paz et al., 2010), we did not boil the crushed chilli pepper. We heated the palm oil before adding the crushed chilli pepper to fry it and make a strong, long-lasting concentrate. Five liters of palm oil were heated in a sauce pan of 101 capacity using a commercial household gas heater. The oil was heated for 10 to 15 minutes until oil started to evaporate, then was removed from the household gas heater, placed far from the gas heater in an open area and crushed peppers were immediately added. The hot cooking oil fried and concentrated the chilli pepper through water dehydration, creating a potent concentrated oil-chilli pepper mixture.

We used the chilli pepper concentrate in three different forms to try to deter elephants: (1) in bottles to release chilli pepper odour, (2) in a wire fence with hung bottles of chilli pepper to target face skin and eye contact, and (3) in mango fruits which were coated with the hot chilli pepper concentrate to reach mouth mucosa if eaten. Mango fruits were coated with the chilli pepper concentrate by plunging them in a $1.5 \mathrm{dm}^{3}$ sauce pan filled with the chilli pepper concentrate. We used recycled plastic water bottles and modified them by making two opposite openings of $5 \mathrm{~cm} \times 5 \mathrm{~cm}$ at $5 \mathrm{~cm}$ from the bottle bases. This enabled bottles to release the odour of the chilli pepper concentrate and allowed the concentrate to spill out when bottles were moved or displaced. All bottles were filled with $150-200 \mathrm{~cm}^{3}$ of the chilli pepper concentrate every evening to prevent rain diluting and washing away the chilli pepper concentrate.
We set-up three experimental sites (S1, S2 and S3) with the three types of chilli pepper devices. Data from those three sites were compared to a control site (S0) with mango trees, but no chilli pepper deterrents. Each site comprised 1-2 mango trees with similar diameters at breast height (30$40 \mathrm{~cm})$, tree heights $(10-15 \mathrm{~m})$; and most importantly comparable ground canopy cover areas (approximately $100 \mathrm{~m}^{2}$ ) providing similar quantities of mango fruits for elephants to feed. We set one camera trap (RC55 Rapidfire, Reconyx, Holmen, Wisconsin) at each site to record the elephants' reactions and feeding behaviour following Ngama et al. (2016) method and O'Connell et al. (2011) recommendations. Cameras were placed at a height of about $1.5 \mathrm{~m}$ above the ground and at $10 \mathrm{~m}$ to 15 $\mathrm{m}$ from the focal mango trees in order to cover the $100 \mathrm{~m}^{2}$ experimental site areas (O'Connell et al., 2011; Burton et al., 2015; Ngama et al., 2016). The time delay for activation of camera traps was two seconds $(2 \mathrm{~s})$. We checked cameras daily replacing memory cards and verifying that cameras were functioning properly. These sites were monitored during seven consecutive days, from $19^{\text {th }}$ to $25^{\text {th }}$ of November 2011. Experimental sites were visible from the residence of the lead author (Fig. 1) and on some occasions he could directly observe wild elephants. The three experimental sites, S1, S2 and S3 were set to reach respectively elephant smell, eye and mouth senses.

(1) S1: Bottles filled with the chilli pepper concentrate and hung on mango trees to reach elephant olfaction

To assess the efficiency of chilli pepper odour as an elephant repellent, we made a concentrated chilli pepper odour releaser device at the first site (S1). We hung 12 bottles filled with the chilli pepper concentrate in mango tree branches to deter elephants from feeding on ripe fruits. Bottles were hung 2-3 $\mathrm{m}$ from the ground and were 2-3 m apart, allowing elephants to walk easily between bottles without displacing the bottles. Thus, it was possible for elephants to smell the chilli pepper concentrate without spilling and making contact with the chilli concentrate.

\section{(2) S2: Bottles filled with chilli pepper hung on} wired fence to reach elephant face and eyes

To assess the efficiency of chilli to repel elephants after face and eye contact, we made a chilli fence at the second site (S2). We hung bottles of chilli pepper oil separated $0.5 \mathrm{~m}$ apart in a wire, forming a $13 \mathrm{~m}$ long straight-line wire fence of chilli concentrate bottles that obstructed 
the elephant path to the mango trees. The other sides of the mango tree site at S2 were protected by fences separating camp residences. Bottles were hung at 1.5 to $2 \mathrm{~m}$ high so that chilli concentrate would spill at the level of the elephant's face and eyes when passing through the fence and displacing bottles.

(3) S3: Chilli pepper concentrate coated on mango fruits to reach elephant mouth

To assess the deterrent effect of eating chilli pepper, we removed fallen mango fruits at site S3 and coated them with the chilli pepper concentrate as described above. This was repeated each evening.

\section{Statistical analyses}

Three response variables were measured to assess the efficiency of the three chilli devices on deterring elephants from experimental sites. The first response variable is the number of elephant visits to a site. One elephant visit is defined as the presence of one or more elephants at an experimental site as recorded by camera trap photos; regardless of the distance between elephants and the chilli pepper devices. Elephant visit events were considered different if they were separated by at least five minutes lag time. This lag time was determined based on the minimum times it took for elephants to collect all fruits at an experimental site before leaving to another mango tree.

The second response variable is elephant contact with chilli pepper devices and mango fruits. Hence, contact events are defined as one or more sequential pictures depicting elephants touching or passing among hung bottles at site $\mathrm{S} 1$, elephants touching or passing through the fence at site S2, and elephants removing, touching or eating mango fruits at all sites including $\mathrm{S} 3$ and S0. We additionally verified the absence of mango fruits coated with chilli pepper at site S3 every morning as the evidence of elephant eating chilli pepper concentrate in addition to sequential photos of camera traps. As for visits, all contact events recorded within a five minutes lag time were counted as «one single event» on the basis of one or more elephant caught in one or more photos.

The third response variable is «unusual reactions». Chilli peppers contains capsaicin, the chemical compound responsible for their pungency by stimulating nociceptors of the trigeminal system (Karidozo \& Osborn, 2015). Mammals in general and elephants in particular, find these irri- tations and burning sensations unpleasant (Parker \& Osborn, 2006; Karidozo \& Osborn, 2015). We used elephant behaviour at the control site S0 to determine normal reactions. At the control site S0, elephant would come to the site, walk around the tree picking up and eating fruits before leaving. All others activities, such as hesitation to pick up fruits through longer lag times, standing still without picking up fruits, walking backward or removing chilli pepper devices, were considered as unusual reactions. In this process, properly identifying all individual elephants and their reactions was not possible because a single camera trap per site was not sufficient especially at night. For that, if one or more elephant displayed unusual behaviour during a visit, it was counted as one unusual reaction.

We chose to perform non-parametric statistics because we had unbalanced numbers of observations among sites and count data. Following Parker \& Osborn (2006) and Ngama et al. (2016) statistical methods, we used Kruskal-Wallis rank sum and post-hoc Dun tests to check significances of differences in elephant visits, contact events, and unusual reactions between experimental sites. We used ${ }^{\circledR}$ Excel and ${ }^{\circledR} \mathrm{R}$ version 3.4.3 (R Development Core Team, 2017) software to compute data and perform statistical analyses.

\section{Results}

We recorded a total of 4,658 camera trap photographs of forest elephants during the study period, including 212 visits, 169 contact events, and 87 unusual elephant reactions at all experimental sites. All elephant visits occurred between 6 p.m. and 6 a.m. and represented three hours of feeding behaviour at all experimental sites. Apart from unusual reactions the fewest number of events were recorded at site S2 equipped with the chilli pepper fence device, whereas the greatest numbers of events were recorded at the control site S0 with no chilli pepper device present (Table 1).

Visits and contact events were not significantly lower (Kruskal-Wallis $X^{2}=19.1, d f=3, p<0.05$ ) at $\mathrm{S} 1$ than at the control site S0 (Table 1). Although the hung bottles filled with chilli pepper concentrate did not stop elephants from feeding on fruits at site $\mathrm{S} 1$, elephants did pause to look at the bottles (Fig. 2(c)) and an adult elephant even shook its tail, spilling out the chilli pepper concentrate (Figs. 2(e) to 2(i)). On the seventh day of the study elephants broke all bottle wires at site S1 effectively ending the experiment. 
Table 1. Summary of results of elephant events with Kruskal-Wallis rank sum and post-hoc Dun test results at 5\% of confidence. Results in same columns with the same letters are not significantly different at $5 \%$ confidence level

\begin{tabular}{l|c|c|c|}
\hline \multicolumn{1}{c|}{ Sites } & Number of elephant visits & Number of elephant contacts & Number of unusual reaction events \\
\hline S0, control & $68^{\mathrm{a}}$ & $68^{\mathrm{a}}$ & $0^{\mathrm{a}}$ \\
S1, smell & $54^{\mathrm{ab}}$ & $48^{\mathrm{a}}$ & $16^{\mathrm{ab}}$ \\
S2, face and eye contact & $33^{\mathrm{b}}$ & $2^{\mathrm{b}}$ & $30^{\mathrm{bc}}$ \\
S3, mouth contact & $57^{\mathrm{a}}$ & $51^{\mathrm{a}}$ & $41^{\mathrm{c}}$ \\
\hline
\end{tabular}

The number of visits and contacts at the chilli pepper fence (S2) was significantly lower (Kruskal-Wallis $X^{2}=16.4, d f=3, p<0.05$ ) than the other sites including the control S0 (Table 1). The two recorded contact events involved one elephant reversing through the fence to avoid contacting the bottles with its face and a young elephant with the chilli pepper spilt in its face (Fig. 3). Although this young elephant re-visited the site, it did not make contact with the fence again. These contact events occurred on the first night and we recorded no other contact events at the fence.

The chilli pepper concentrate coated on the mango fruits did not deter the elephants from eating the fruits. All new fruits coated with chilli pepper concentrate we placed each evening at S3 were gone the next morning
(Fig. 4). On the first trial day, the elephants spent 38 min. walking around the tree before a young elephant started feeding mango fruits coated with the chilli pepper concentrate and adults followed (Fig. 4). That day, from the window of the residence, the lead author observed that some elephants made unusual sounds after eating fruits coated with the chilli pepper concentrate. On the remaining days, the elephants started eating fruits immediately, but still showed unusual reactions. The number of elephant visits and contacts at site S3 were not significantly different from the control site S0 and site S1 (Table 1). Yet, the number of unusual elephant reactions at site S3 was significantly higher (Kruskal-Wallis $X^{2}=18.7, d f=3, p<0.05$ ) than at sites $\mathrm{S} 1$ and S0 (Table 1).

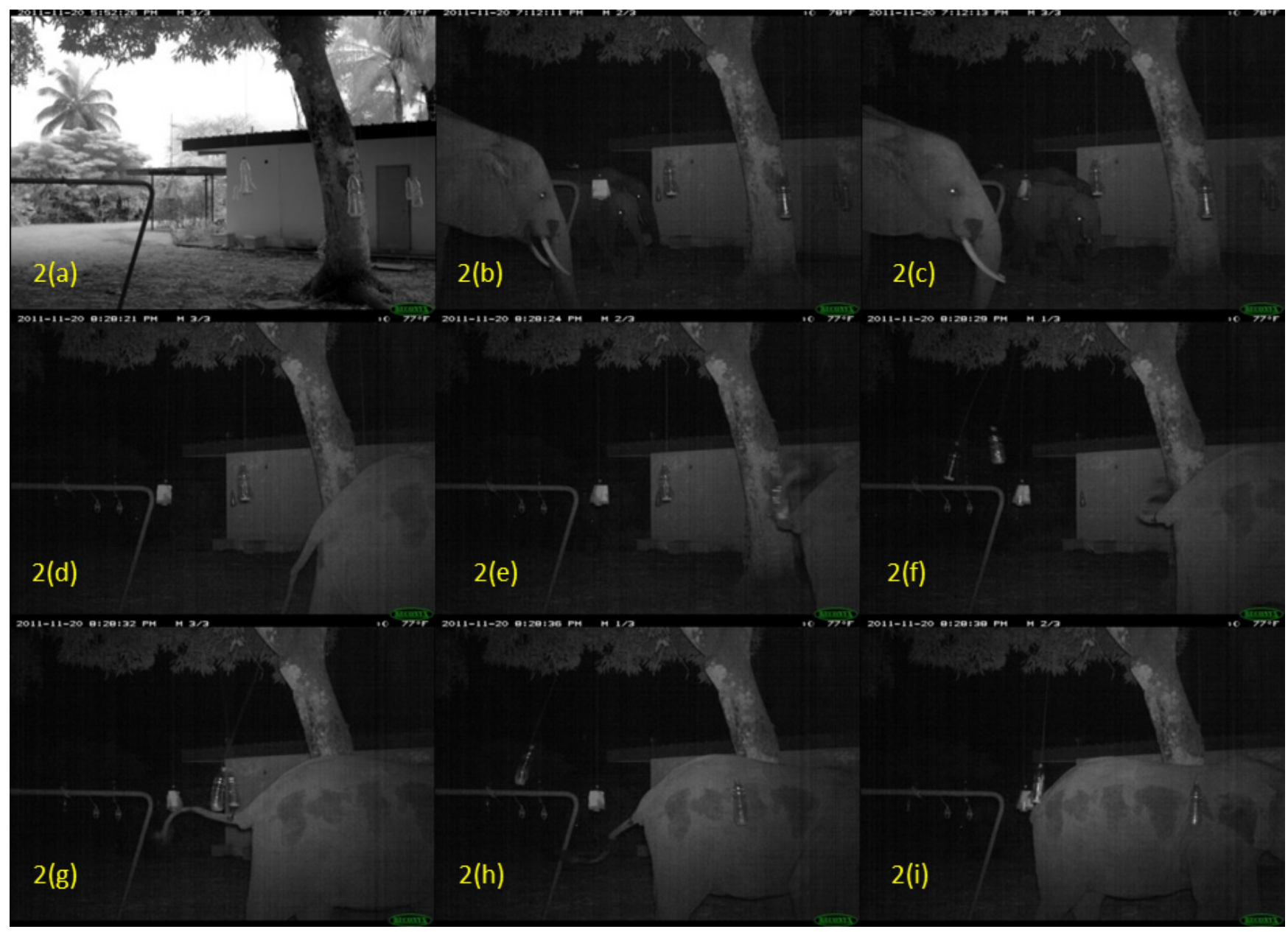

Fig. 2. Photos from S1 showing elephant behaviour. Picture 2(a) shows bottles with the chilli pepper concentrate hung in the mango tree. Elephants start collecting and eating fallen mango (2(b), 2(c)). In pictures 2(b) and 2(c) the elephant with the longer tusks looks at the chilli pepper bottles. In sequential photos from 2(d) to 2(i), this same elephant reverses into the bottles while shaking its tail, resulting in chilli concentrate spilled onto the body of the elephant. 


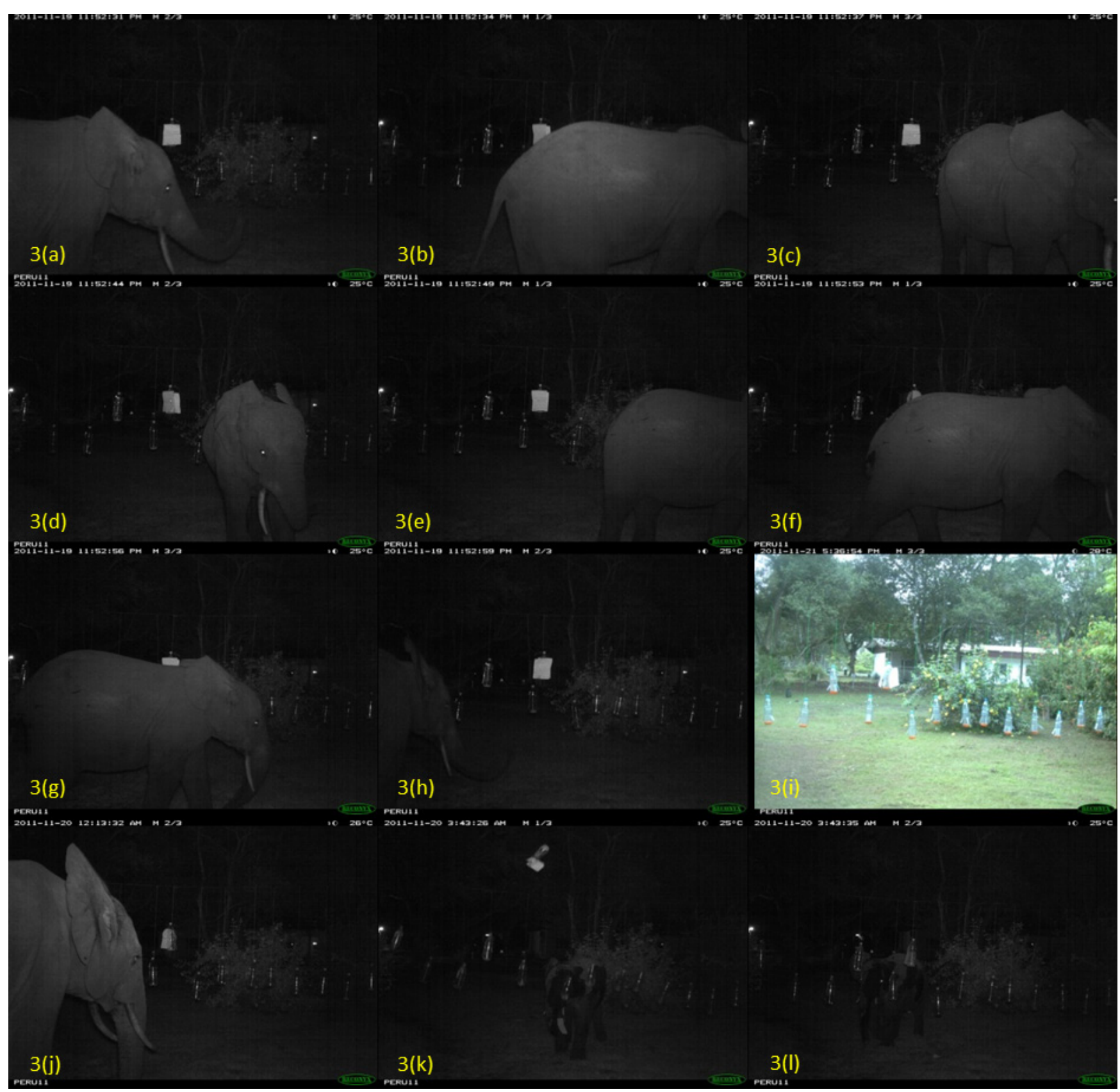

Fig. 3. Pictures from S2 of the elephant contact events with the chilli fence device. Picture 3(i) shows the chill pepper fence device with mango trees in its background. Photos 3(a) to 3(h) show the first contact event of an elephant with the chilli pepper fence device where the elephant reversed into the chilli fence device and walked away from the fence. Photos $3(\mathrm{k})$ and 3(l) are the contact event of a young elephant with the chilli fence. Picture 3(j) shows an adult elephant looking at the chilli fence before moving back.

\section{Discussion}

The use of camera traps showed to be a useful tool to examine how wild forest elephants react to chilli pepper used as a repellent while feeding on mango fruits. This supports the utility of camera traps to study wild animals (Trolliet et al., 2014). Despite the rather short seven-day duration of the study, the sample size of 212 elephants visit events representing three hours of elephant foraging, provides a good starting point for understanding how wild forest elephants react to devices using chilli pepper as a deterrent. A chilli pepper device that resulted in splashing concentrate on the elephant's face proved to be the most effective at deterring elephants. Surprisingly, chilli pepper concentrate applied directly to mango fruits did not deter elephants from eating the fruits, although it caused the most discomfort. Sequential camera trap photos showed elephants eating these fruits.

Elephants showed signs of distress when they ate fruits coated with pepper and this is in accordance with other trial records (Osborn \& Rasmussen, 1995). With camera trap images we could see that elephants neither moved off nor stopped eating fruits; 
they endured irritations and burning sensations of chilli pepper concentrate. This does not support the previous statement that elephants cannot eat chilli pepper (Parker \& Osborn, 2006). Most interestingly the control site S0 and the site S3 with chilli pepper concentrate coated on the mango had a similar number of elephant events with the exception of the unusual reactions. Despite the irritation of the pepper causing unusual reactions, elephants eat mango fruits coated with the chilli pepper concentrate. Capsaicin from chilli pepper has dose-dependent effects (Ameh et al., 2015; Srinivasan, 2016). The elephant's willingness to eat fruits coated with chilli pepper during this trial might be due to the amount of the chilli pepper which was coated on fruits while plunging them in the concentrate, and which had not enough strong repellent effect on elephants.

The amount of capsaicin spiciness is estimated at about $16 \times 10^{6}$ Scoville Heat Units enabling it to cause a burning sensation when it comes in contact with mucous membranes, stinging pain to the skin, and if ingested in large amounts, it can produce nausea, vomiting, abdominal pain and burning diarrhea
(Ameh et al., 2015; Srinivasan, 2016). As elephants continued to consume mango fruits coated with the chilli pepper concentrate such effects had not been observed. During the trial, elephants showed higher signs of distress when eating fruits coated with chilli pepper; but their distress was low at the device releasing chilli pepper smell. This means that elephants might be less sensitive to chilli pepper smell. The greatest unusual reactions recorded at site S3 indicates that elephants might have been deterred with a stronger concentrated chilli pepper. Yet, the use of a more concentrated chilli pepper raises concerns about lethal effects of capsaicin (Ameh et al., 2015; Srinivasan, 2016). Capsaicin effects are also known to decrease as consumers become habituated (Srinivasan, 2016) explaining why elephant were less willing to eat mongo fruits coated with chilli pepper the first trial day compared to the other days. It might be interesting to conduct further research to find out the optimal chilli pepper concentration which could efficiently prevent elephant from feeding on fruits or crops while not causing noxious overdose effects.

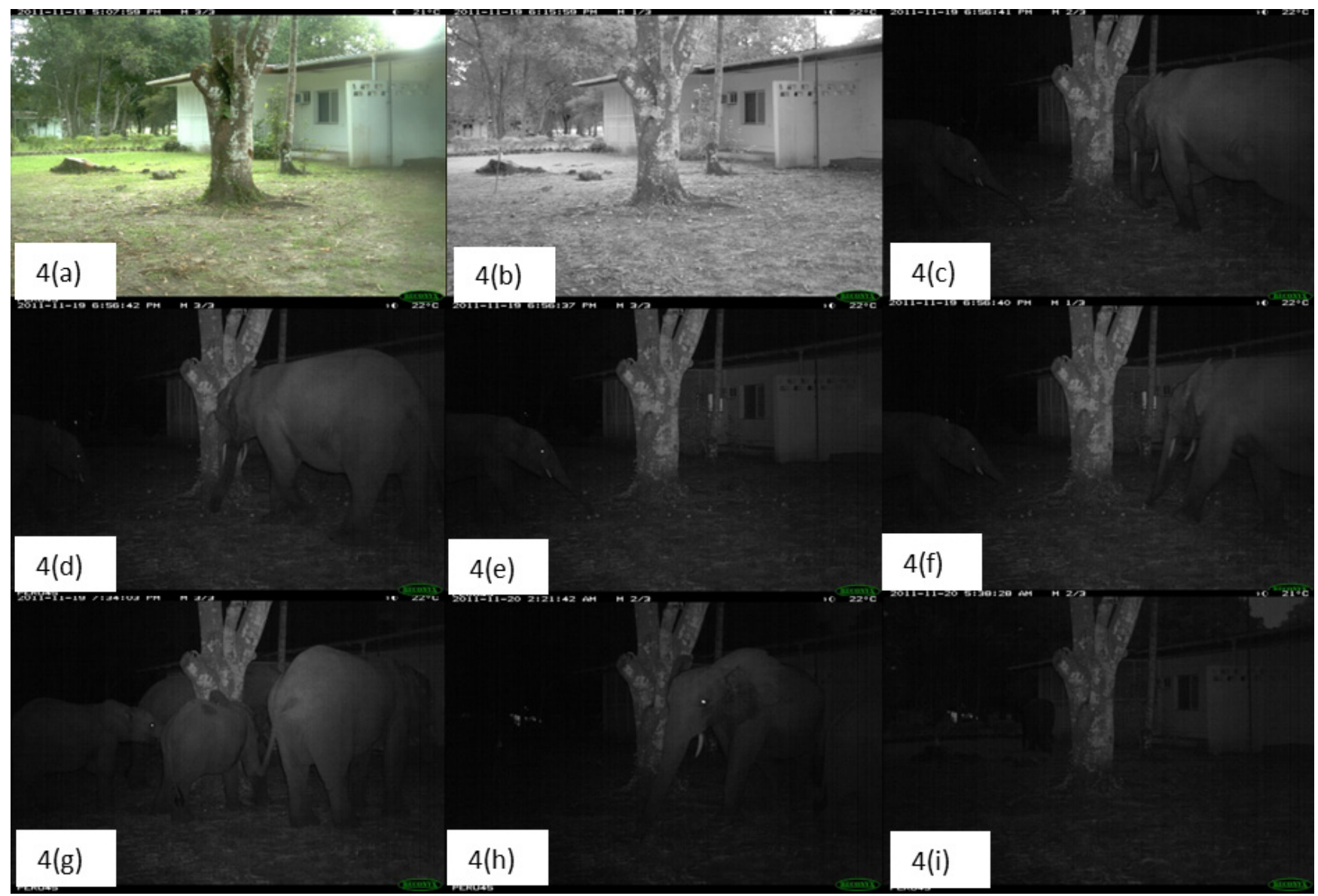

Fig. 4. Photos from site S3 with fruits coated with the chilli pepper concentrate. At the start of each night we removed all mango fruits as shown in Photo 4(a). Just before sunset, chilli concentrate coated fruits were put at the site (Photo 4(b)). The lead author residence is in the background; he could make some observations through the windows (4(a), 4(b)). In photos 4(c) to 4(h), elephants are collecting and eating mango fruits including newly fallen and those coated with the chilli pepper concentrate. Early morning the next day, all mango fruits were eaten (4(i)). 
Our results show that elephants mostly avoided face contact with the fence device, suggesting that the most effective use of the chilli pepper concentrate is when it reaches the elephant eye mucosa. Eye exposure to chilli pepper produces intense tearing and pain (Srinivasan, 2016). This might explain why at site S2 the elephant reversed while challenging the chilli fence (Fig. 4) and the young elephant which received chilli pepper on its face never returned to make contact with the fence (Fig. 4) and no more contact events were recorded thereafter. These results support previous data about the reliability of chilli pepper fences as elephant repellents (Chang'a et al., 2016). Hence, the efficiency of chilli pepper might depend on its possibility to reach the face of elephants. Unfortunately, devices used during this study consumed lot of chilli pepper quantities as in other experiments (Parker \& Osborn, 2006; Le Bel et al., 2015; Chang'a et al., 2016). Yet, chilli peppers are costly crops (Wiafe \& Sam, 2014; Le Bel et al., 2015; Chang'a et al., 2016). This has led us to prematurely end our trial after the elephants removed devices at site S1 and may reduce the use chilli pepper as elephant deterrent in general. The future works should focus on exploring best practices for reaching only the face which is the most sensitive elephant body part taking into account the least and safe quantity of chilli pepper which will have the strongest deterrent effects.

\section{Acknowledgements}

We thank the National Center for Scientific and Technological Research (Centre National de la Recherche Scientifique et Technologique, CENAREST) in Gabon for permission to conduct this research. We are particularly grateful for the cooperation of the Smithsonian Conservation Biology Institute's Gabon Biodiversity Program staff. We thank Marguerite Butler, Elie Tobi, and David Korte for their generous help with logistics and field work. We are so thankful to the unknown reviewers who made helpful comments for the final manuscript. This is contribution \#160 of the Smithsonian Conservation Biology Institute's Gabon Biodiversity Program. The Health, Safety and Environment (HSE) Department of Shell Gabon provided financial support for field work to SN, LK and MJ. Shell Gabon provided logistical support, including flights, lodging, transportation, and meals to SN. Gembloux Agro-Bio Tech, University of Liège (Belgium) provided financial support for the manuscript writing to SN.

\section{References}

Ameh S.J., Ibekwe N.N., Ebeshi B.U. 2015. Essential Oils in Ginger, Hops, Cloves, and Pepper Flavored Beverages - A Review. Journal of Dietary Supplements 12: 241-260. DOI: 10.3109/19390211.2014.952858
Blanc J.J, Barnes R.F.W., Craig G.C., Dublin H.T., Thouless C.R., Douglas-Hamilton I., Hart J.A. 2007. African elephant status report 2007: an update from the African Elephant Database. Gland, Switzerland: IUCN. 275 p. DOI 10.2305/IUCN.CH.2007.SSC-OP.33.en

Blanc J., Bumham K., Dublin H., Milliken T., Mwangi P., Sangalakula L., Skinner D., Underwood F. 2013. Status of African Elephant Populations and Levels of Illegal Killing and the Illegal Trade in Ivory: A Report to the African Elephant Summit Gland, Switzerland: IUCN. 31 p. Available from https://cmsdata.iucn.org/downloads/african_elephant_summit background_document_2013_en.pdf. Retrieved on 22 April 2018.

Burton A.C., Neilson E., Moreira D., Ladle A., Steenweg R., Fisher J.T., Bayne E., Boutin S. 2015. Wildlife camera trapping: a review and recommendations for linking surveys to ecological processes. Journal of Applied Ecology 52: 675-685. DOI: 10.1111/13652664.12432

Chang'a A., de Souza N., Muya J., Keyyu J., Mwakatobe A., Malugu L., Ndossi H.P., Konuche J., Omondi R., Mpinge A., Hahn N., Palminteri S., Olson D. 2016. Scaling-up the use of chili fences for reducing human-elephant conflict across landscapes in Tanzania. Tropical Conservation Science 9: 921-930. DOI: 10.1177/194008291600900220

Chuah A.M., Lee Y.-C., Yamaguchi T., Takamura H., Yin L.J., Matoba T. 2008. Effect of cooking on the antioxidant properties of coloured peppers. Food Chemistry 111(1): 20-28. DOI: 10.1016/j.foodchem.2008.03.022

Csilléry G. 2006. Pepper taxonomy and the botanical description of the species. Acta Agronomica Hungarica 54(2): 151-166. DOI: 10.1556/AAgr.54.2006.2.5

Fairet E.M.M. 2012. Vulnerability to crop raiding an interdisciplinary investigation in Loango National Park, Gabon. PhD Thesis. Durham University, UK. Available from http://etheses.dur.ac.uk/6399/1/EmilieFairet_Thesis_Finaldraft_08022013.pdf

Hedges S., Gunaryadi D. 2010. Reducing human-elephant conflict: do chillies help deter elephants from entering crop fields? Oryx 44(1): 139-146. DOI: 10.1017/ S0030605309990093

Hoare R. 2015. Lessons from 20 years of human-elephant conflict mitigation in Africa. Human Dimensions of Wildlife 20(4): 289-295. DOI: 10.1080/10871209.2015.1005855

Howe E.J., Buckland S.T., Després-Einspenner M.-L., Kühl H.S. 2017. Distance sampling with camera traps. Methods in Ecology and Evolution 8(11): 1558-1565. DOI: 10.1111/2041-210X.12790

Inogwabini B.-I., Mbende L., Bakanza A., Bokika J.C. 2013. Crop damage done by elephants in Malebo Region, Democratic Republic of Congo. Pachyderm 54: 59-65.

Karidozo M., Osborn F.V. 2015. Community Based Conflict Mitigation Trials: Results of Field Tests of Chilli 
as an Elephant Deterrent. Journal of Biodiversity \& Endangered Species 3(1): 144. DOI: 10.4172/23322543.1000144

Lahm S.A. 1993. Ecology and Economics of Human/Wildlife Interaction in Northeastern Gabon. PhD Thesis. New York University, USA.

Le Bel S., La Grange M., Drouet N. 2015. Repelling elephants with a chilli pepper gas dispenser: field tests and practical use in Mozambique, Zambia and Zimbabwe from 2009 to 2013. Pachyderm 56: 87-96.

Lee M.E., Alonso A., Dallmeier F., Campbell P., Pauwels O.S. 2006. The Gamba complex of protected areas: an illustration of Gabon's biodiversity. Bulletin of the Biological Society of Washington 12: 229-241.

Maisels F., Strindberg S., Blake S., Wittemyer G., Hart J., Williamson E.A., Aba'a R., Abitsi G., Ambahe R.D., Amsini F., Bakabana P.C., Hicks T.C., Bayogo R.E., Bechem M., Beyers R.L., Bezangoye A.N., Boundja P., Bout N., Akou M.E., Bene L.B., Fosso B., Greengrass E., Grossmann F., Ikamba-Nkulu C., Ilambu O., Inogwabini B.I., Iyenguet F., Kiminou F., Kokangoye M., Kujirakwinja D., Latour S., Liengola I., Mackaya Q., Madidi J., Madzoke B., Makoumbou C., Malanda G.A., Malonga R., Mbani O., Mbendzo V.A., Ambassa E., Ekinde A., Mihindou Y., Morgan B.J., Motsaba P., Moukala G., Mounguengui A., Mowawa B.S., Ndzai C., Nixon S., Nkumu P., Nzolani F., Pintea L., Plumptre A., Rainey H., de Semboli B.B., Serckx A., Stokes E., Turkalo A., Vanleeuwe H., Vosper A., Warren Y. 2013. Devastating Decline of Forest Elephants in Central Africa. PLoS ONE 8: e59469. DOI: 10.1371/journal.pone.0059469

Mariki S.B., Svarstad H., Benjaminsen T.A. 2015. Elephants over the Cliff: Explaining Wildlife Killings in Tanzania. Land Use Policy 44: 19-30. DOI: 10.1016/j. landusepol.2014.10.018

Ngama S., Korte L., Bindelle J., Vermeulen C., Poulsen J.R. 2016. How Bees Deter Elephants: Beehive Trials with Forest Elephants (Loxodonta africana cyclotis) in Gabon. PLoS ONE 11: e0155690. DOI: 10.1371/ journal.pone. 0155690

O’Connell A.F., Nichols J.D., Karanth K.U. (Eds.). 2011. Camera Traps in Animal Ecology: Methods and Analyses. Springer Japan. 271 p. DOI: 10.1007/9784-431-99495-4

Ornelas-Paz J. de J., Martínez-Burrola J.M., Ruiz-Cruz S., Santana-Rodríguez V., Ibarra-Junquera V., Olivas G.I., Pérez-Martínez J.D. 2010. Effect of cooking on the capsaicinoids and phenolics contents of Mexican peppers. Food Chemistry 119(4): 1619-1625. DOI:

10.1016/j.foodchem.2009.09.054

Osborn F.V., Rasmussen L.E.L. 1995. Evidence for the effectiveness of an oleo-resin capsicum aerosol as a repellent against wild elephants in Zimbabwe. Pachyderm 20: 55-64.

Parker G.E., Osborn F.V. 2006. Investigating the potential for chilli Capsicum spp. to reduce human-wildlife conflict in Zimbabwe. Oryx 40(3): 343-346. DOI: 10.1017/S0030605306000822

Poulsen J.R., Koerner S.E., Moore S., Medjibe V.P., Blake S., Clark C.J., Akou M.E., Fay M., Meier A., Okouyi J., Rosin C., White L.J.T. 2017. Poaching empties critical Central African wilderness of forest elephants. Current Biology 27(4): R134-R135. DOI: 10.1016/j.cub.2017.01.023

R Development Core Team. 2017. R: A Language and Environment for Statistical Computing. Available from: https://www.R-project.org/

Smit J., Pozo R.A., Cusack J.J., Nowak K., Jones T. 2017. Using camera traps to study the age-sex structure and behaviour of crop-using elephants Loxodonta africana in Udzungwa Mountains National Park, Tanzania. Oryx: 1-9. DOI: 10.1017/S0030605317000345

Srinivasan K. 2016. Biological Activities of Red Pepper (Capsicum annuum) and Its Pungent Principle Capsaicin: A Review. Critical Reviews in Food Science and Nutrition 56(9): 1488-1500. DOI: 10.1080/10408398.2013.772090

Tchamba M.N. 1995. The Problem Elephants of Kaélé: a Challenge for Elephant Conservation in Northern Cameroon. Pachyderm 19: 26-32.

Trolliet F., Huynen M.-C., Vermeulen C., Hambuckers A. 2014. Use of camera traps for wildlife studies. A review. Biotechnology, Agronomy, Society and Environment 18(3): 446-454.

Walker K.L. 2010. Moving away from prescriptive pachyderm palliatives: toward an integrated assessment of farmer-elephant conflict in Gabon. PhD Thesis. University of Michigan, USA. 127 p.

Walker K.L. 2012. Labor costs and crop protection from wildlife predation: the case of elephants in Gabon. Agricultural Economics 43(1): 61-73. DOI: 10.1111/j.1574-0862.2011.00565.x

Wiafe E.D., Sam M.K. 2014. Evaluation of a low-tech method, pepper-grease, for combatting elephant cropraiding activities in Kakum Conservation Area, Ghana. Pachyderm 55: 38-42. 
ФОТОЛОВУШКИ ДЛЯ ИЗУЧЕНИЯ ОТВЕТА ЛЕСНОГО СЛОНА (LOXODONTA CYCLOTIS) НА ПЕРЦОВЫЕ РЕПЕЛЛЕНТЫ В ГАМБЕ (ГАБОН)

\author{
С. Нгама ${ }^{1,2}$, Л. Корте ${ }^{3}$, М. Джонсон ${ }^{3}$, С. Вермеулен ${ }^{1}$, Дж Бинделль ${ }^{1}$ \\ ${ }^{1}$ Сельскохозяйственный университет Жамблу, Льежский университет, Бельгия \\ e-mail:steeve.ngama@doct.uliege.be,cvermeulen@uliege.be,jerome.bindelle@uliege.be \\ ${ }^{2}$ Научно-исследовательский институт агрономического и лесного хозяйства Начионального иентра \\ научных и технологических исследований, Габон \\ e-mail: steeve_ngama@yahoo.fr \\ ${ }^{3}$ Смитсоновский институт биологии сохранения, Программа биоразнообразия Габона, США \\ e-mail:lisakorte@earthlink.net,JohnsonMI@si.edu
}

\begin{abstract}
В Центральной Африке Габон является облесенной страной с богатым биоразнообразием, где конфликт междудикимиживотнымиилюдьмиявляетсяобычнымявлениемиприводиткбесчисленнымповреждениям сельскохозяйственных культур. Слоны являются худшими животными в этом отношении, так как за одну ночь могут уничтожить весь урожай за одну ночь. Эти налеты животных угрожают жизням людей так же, как и слонов, потому что фермеры часто убивают животных в ответ на уничтожение урожая. Чтобы держать слонов за пределами ферм, рекомендуется использование перца чили в качестве нелетального метода. Но в Габоне имеется лишь несколько исследований, в которых был протестирован метод использования перца чили для сдерживания налетов слонов. Результаты настоящего исследования являются отправной точкой для понимания того, как лесные слоны реагируют на устройства с использованием перца чили в качестве сдерживающего средства на основе последовательных снимков фотоловушек. Устройство перца чили, разбрызгивающее его концентрат на морду слона, оказалось наиболее эффективным при сдерживании животных. Неожиданным оказалось то, что концентрат перца чили, непосредственно примененный к плодам манго, не сдерживал слонов от их употребления, хотя это, вероятно, вызывало дискомфорт. Для создания эффективных средств сдерживания слонов с использованием концентрата перца чили, будущие работы должны сосредоточиться на изучении практического применения метода, чтобы концентрат перца достигал морды слона с наименьшим безопасным количеством перца чили, которое, в то же время, имело бы достаточно сильный сдерживающий эффект.
\end{abstract}

Ключевые слова: Габон, лесной слон, перец чили, фотоловушка, Центральная Африка 